\title{
Synthesis, spectral, thermal, optical dispersion and dielectric properties of nanocrystalline dimer complex (PEPyr-diCd) thin films as novel organic semiconductor
}

\author{
AHMED FAROUK AL-HOSSAINY \\ Chemistry Department, Faculty of Science—New Valley, Assiut University, 71516 Assiut, Egypt
}

MS received 5 May 2015; accepted 31 August 2015

\begin{abstract}
Dimer complex PEPyr-diCd (5a) has been prepared by reacting $\mathrm{CdCl}_{2} \cdot 2.5 \mathrm{H}_{2} \mathrm{O}$ with $1, \mathbf{1}^{\prime}$ bis(diphenylphosphino)ethyl-6-methyl-3-(pyridin-2-yl)-1,4-dihydro-pyridazine tungsten tetracarbonyl PEPyr (4a) as bipyridine ligand. The structural properties of PEPyr-diCd complex were characterized on the basis of elemental analysis (EA), Fourier transform infrared spectra, fast atom bombardment-mass spectrometry, thermogravimetric/differential thermal analysis, and ${ }^{\mathbf{1}} \mathrm{H}$ nuclear magnetic resonance spectroscopy. The crystal is orthorhombic, space group Pbca. Cd(II) metal in PEPyr-diCd organic semiconductor complex coordinated with two $\mathrm{N}$ of the PEPyr and three $\mathrm{Cl}^{-}$(one terminal and two bridging). The micro-structural properties of the films were studied via $\mathrm{X}$-ray diffraction, and scanning electron microscopy. The as-deposited films were annealed in air for $1 \mathrm{~h}$ at 150,200 , and $250^{\circ} \mathrm{C}$. An average transmittance $\geq 70 \%$ for PEPyr-diCd complex at higher wavelength $\geq 800$ nm was observed. In UV spectrum, the transmittance increases followed by a sharp decrease at wavelength 700-750 nm within visible range. The results of the absorption coefficient were determined to find the binding energy $\left(E_{B}\right)$ of PEPyr-diCd organic semiconductor complex as 0.242 and $0.47 \mathrm{eV}$, respectively. Refractive index (n) and absorption index $(K)$ of PEPyr-diCd complex were calculated. Moreover, the dispersion parameters such as dispersion energy, oscillator energy, dielectric constant, and dissipation factor were determined. The oxidation of the imino-phosphine derivatives were examined using cyclic voltammetry in methylene chloride solvent. The cyclic voltammogram of PEPyrdiCd (5a) organic semiconductor appears to have two quasi-reversible oxidations at 543 and $441 \mathrm{mV}$. The obtained results indicate that the PEPyr-diCd organic semiconductor thin film is a good candidate in optoelectronic devices based on its band gap and dispersion parameters.
\end{abstract}

Keywords. Diphenylphosphino-ethane derivatives; cadmium (II) dimer organic semiconductor thin films; optical dispersion and dielectric properties.

\section{Introduction}

In recent years the search for nonlinear optical materials is much more because of their applications in optoelectronics and photonics, especially, the optoelectronic devices based on organic semiconductors such as organic field-effect transistors (OFETs) [1], organic light-emitting diodes (OLEDs) [2], organic solar cells [3] and sensors [4]. Among the organic semiconductors, imino-phosphine and its derivatives have a particular status because of their specific electrical, optical properties and good thermal stabilities [5]. These imino-phosphine organic compounds have been used in many applications such as solar cells and OLEDs [6-8].

Structural characterization of pyridine-phosphine chalcogenide ligands with cadmium (II) in $\mathrm{EtOH}$ at room temperature to obtain complexes of compositions $3 \mathrm{CdCl}_{2} \cdot 2 \mathrm{~L}$ produce high yields and has been proved by $\mathrm{X}$-ray analysis data. The type of this complex exists as polymeric chains with each bridging ligand acting as a chelate N, S- or N, Sedonor to one cadmium(II) centre and as a pyridine $\mathrm{N}$-donor

(ahmed73chem@scinv.au.edu.eg) to the next cadmium(II) centre [9]. Recent years have also witnessed a renaissance of interest in the study of multidentate nitrogen-donor ligands (in particular, containing pyridine fragments) and their use in homogeneous catalysis [10]. In addition, pyridyl ligands form often labile metal ligand bonds that can be used in self-assembly of coordination polymers and network materials [11].

Imino-phosphine ligands and their derivatives such as 2,2bipyridine (bpy), 2,2-bipyridylamine (bpa), and 1,10-phenanthroline (phen) are suitable in particular emphasis on developing new metal complexes with extended planar aromatic ligands to enhance non-covalent binding to transition metal ions [12]. Due to rotational flexibility around the carboncarbon single bond bridging the two pyridine rings of bpy, and the central amine bridging the two pyridine rings of bpa, the two pyridine planes adopt either a coplanar or tilted conformation in coordination with the metal centres [13]. However, such rotational flexibility is not possible for phen ligands, which remain coplanar even after metal coordination.

In continuing our interest with novel imino-phosphinetransition metals complexes, optical measurements were carried out in the incident photon energy range 1.40-2.64 eV 
over the temperature range of 77-300 K [14]. By using the energy dependence of the absorption coefficient, it was clear that in the short wavelength region, the absorption coefficient linearly increases for the imino-phosphine crystals with the increase in the incident photon energy. In addition, the optical measurements exhibit direct allowed transitions in the Cu-dppm organic crystalline semiconductor $[15,16]$.

In this paper, the formation of PEPyr-diCd organic semiconductor crystalline nanostructure thin film by using transition metal $\left(\mathrm{CdCl}_{2} \cdot 2.5 \mathrm{H}_{2} \mathrm{O}\right)$ and a derivatives of iminophosphine chelating ligands ranging in size and the presence or absence of $\pi$ bonds in the carbon backbones, such as DPPEH (2a) and 1,1'-bis(diphenylphosphino)ethyl-6-methyl3-(pyridin-2-yl)-1,4-dihydropyridazine tungsten tetracarbonyl PEPyr (4a) were investigated. Two chelated products were isolated and structurally characterized using methods such as Fourier transform infrared (FT-IR), ultraviolet-visible (UVvis) and nuclear magnetic resonance spectroscopies as well as X-ray diffraction (XRD), scanning electron microscope (SEM), and cyclic voltammetry. Finally, the optical properties of the DPPEH, PEPYR and PEPyr-diCd nanostructure thin films deposited on quartz substrate manufactured by the thermal evaporation technique are obtained with different annealing temperatures.

\section{Experimental}

\subsection{Materials}

Briefly, 1,1'-bis(diphenylphosphino)ethene tungsten tetracarbonyl complex (1a) [17,18], hydrazine, 1-(pyridin-2-yl)pentane-1,4-dione and 99.9\% cadmium chloride Hemi (pent hydrate) were obtained from Aldrich. Ethanol, $n$-decane and dichloro-methane were supplied from POCh.

2.2 Synthesis of di- $\mu$-chloro-1,1'-bis[chloro(diphenylphosphino)ethyl-6-methyl-3-(pyridin-2-yl)-1,4-dihydro-pyridazine tungsten tetracarbonyl) cadmium (II)] dimer complex

2.2a Synthesis of 1,2-bis(diphenylphosphino)ethyl) hydrazine DPPEH (2a): One mmol (0.692 g) of 1,1'-bis(diphenylphosphino)ethene tungsten tetracarbonyl complex (1a) dissolved in $5 \mathrm{ml}$ of $\mathrm{CH}_{2} \mathrm{Cl}_{2}$ at room temperature and then a solution of $1 \mathrm{mmol}(0.032 \mathrm{~g})$ of hydrazine in $3 \mathrm{ml} n$-decane was added dropwise. This solution was heated to $110^{\circ} \mathrm{C}$ under argon atmosphere. The reaction mixture was stirred for $10 \mathrm{~h}$ at $110^{\circ} \mathrm{C}$. This mixture was cooled to room temperature and precipitate was separated.

DPPEH: A pale yellow. Yield: 73\%. EA: found (calcd) \% C 49.81 (49.75), H 3.60 (3.62), N 3.88 (3.87). MS (FAB): $\mathrm{M}^{+}(\mathrm{m} / \mathrm{z}) 724.17$ (99.4\%), 726.14 (83.47\%), 721.95 (70.80\%), 723.11 (60.42), 725.17 (29.75) and 727.82 $(26.15 \%)$. IR $\left(\mathrm{KBr}, \mathrm{cm}^{-1}\right): 3335(v \mathrm{NH}), 3147(\nu \mathrm{PhH})$, $2987(\nu \mathrm{CH}), 1545(\nu \mathrm{C}=\mathrm{C}),(2052 \mathrm{~s}, 2000 \mathrm{~m}, 1975 \mathrm{~m}, 1977 \mathrm{w})$ $(v \operatorname{sym}(\mathrm{C} \equiv \mathrm{O}))$ and $(720 \mathrm{sh}, 694 \mathrm{~s})(\nu \mathrm{P}-\mathrm{C}) .{ }^{1} \mathrm{H} \mathrm{NMR}\left(\mathrm{CD}_{3} \mathrm{Cl}\right.$, $\delta$, ppm): $2.17-2.22\left(\mathrm{mb},-\mathrm{CH}_{2}-\mathrm{N} \underline{\mathrm{H}}-\mathrm{N}_{2}, 3 \mathrm{H}\right), 2.63-6.65$ (m, -CH- $\left.\underline{\mathrm{CH}}_{2}-, 2 \mathrm{H}\right), 6.15-6.24(\mathrm{~m},-\mathrm{P}-\underline{\mathrm{CH}}-\mathrm{P}, 1 \mathrm{H}), 7.27-$ 8.31 (m, aromatic ring, 20H).

2.2b Synthesis of 1,1'-bis(diphenylphosphino)ethyl-6-methyl3-(pyridin-2-yl)-1,4-dihydropyridazine tungsten tetracarbonyl PEPyr (4a): Application of condensation and elimination $\left(1 \mathrm{M}, \mathrm{H}_{2} \mathrm{O}\right)$ reaction for a mixture of $1: 1 \mathrm{M}$ ratio of DPPEH $(0.724 \mathrm{~g}, 0.001 \mathrm{M})$ and 1-(pyridin-2-yl)pentane-1,4-dione $(0.177 \mathrm{~g}, 0.001 \mathrm{M})$ was refluxed in $n$-decane, at $110^{\circ} \mathrm{C}, 6 \mathrm{~h}$ under nitrogen. The precipitate obtained was filtered, washed several times with ethanol, and dried at $60^{\circ} \mathrm{C}$ in vacuum.

PEPyr: Brown powder. Yield: $81 \%$. EA: found (calcd) \% C 55.57 (55.51), H 3.83 (3.84), N 4.89 (4.86). MS (FAB): $\mathrm{M}^{+}(\mathrm{m} / \mathrm{z}) 865.37$ (98.73\%), $867.01(81.00 \%), 863.52$ (67.27\%), 866.71 (38.19), 864.72 (37.31) 868.57 (31.76), and $864.09(29.32 \%)$. IR $\left(\mathrm{KBr}, \mathrm{cm}^{-1}\right): 3175(\nu \mathrm{PhH}), 2997$ $(\nu \mathrm{CH}), 1541(\nu \mathrm{C}=\mathrm{C}),(2025 \mathrm{~s}, 1994 \mathrm{~m}, 1970 \mathrm{~m}, 1973 \mathrm{w})$ $(v \operatorname{sym}(\mathrm{C} \equiv \mathrm{O}))$, and $(725 \mathrm{sh}, 697 \mathrm{~s})(v \mathrm{P}-\mathrm{C}) .{ }^{1} \mathrm{H} \mathrm{NMR}\left(\mathrm{CD}_{3} \mathrm{Cl}\right.$, $\delta$, ppm): 1.61-1.73 (m, -N-C-C $\left.\underline{H}_{2}-\mathrm{CH}-, 2 \mathrm{H}\right), 2.32(\mathrm{~s}-,-\mathrm{N}-$ $\left.\mathrm{C}-\mathrm{CH}_{3}, 3 \mathrm{H}\right), 2.81-2.83\left(\mathrm{~m},-\mathrm{CH}-\mathrm{CH}_{2}-\mathrm{N}-, 2 \mathrm{H}\right), 5.60-5.62$ $(\mathrm{m}, \mathrm{C}=\underline{\mathrm{CH}}-\mathrm{C}, \mathrm{H}), 6.45-6.53(\mathrm{~m},-\mathrm{P}-\underline{\mathrm{CH}}-\mathrm{P}, 1 \mathrm{H}), 7.27-8.31$ (m, aromatic ring, $20 \mathrm{H}), 8.24-8.33(\mathrm{~m},-\mathrm{N}=\mathrm{C} \underline{\mathrm{H}}-\mathrm{C} \underline{\mathrm{H}}-\mathrm{C} \underline{\mathrm{H}}-$ C

2.2c Synthesis of PEPyr-diCd (5a): A solution of PEPyr ( $0.865 \mathrm{~g}, 1 \mathrm{mmol}$ ) in $5 \mathrm{ml} \mathrm{CH} \mathrm{Cl}_{2}$ was added to a solution of $\mathrm{CdCl}_{2} \cdot 2.5 \mathrm{H}_{2} \mathrm{O}(0.228 \mathrm{~g}, 1 \mathrm{mmol})$ in $10 \mathrm{ml}$ dry ethanol and the mixture was then stirred for $3 \mathrm{~h}$ at room temperature in an open atmosphere. The solution obtained was concentrated to approximately $1 \mathrm{ml}$ under reduced pressure and mixed with $40 \mathrm{ml}$ diethyl ether [19,20]. Crystals suitable for XRD experiments were obtained by diethyl ether diffusion to a solution in $\mathrm{CH}_{2} \mathrm{Cl}_{2}$. Pale brown prisms were isolated after 4 days.

PEPyr-diCd: Pale brown powder. Yield: $1.62 \mathrm{~g}, 82 \%$. EA: found (calcd) \% C 45.80 (45.81), H 3.20 (3.17), N 4.11 (4.01). MS (FAB): $\mathrm{M}^{+}(\mathrm{m} / \mathrm{z}): 2095.24$ (96.74\%), 2097.18 (95.06\%), 2098.14 (94.40\%), 2095.00 (91.68\%), 2099.00 (83.91\%), 2094.04 (80.75\%), 2099.19 (73.19\%), 2098.37 (72.79\%), 2100.3 (70.83\%), 2099.93 (69.97\%), 2097.038 (67.77\%), 2092.79 (63.00\%), $2101.12(58.14 \%), 2095.00$ (56.67\%), 2101.27 (55.73\%), 2092.03 (43.75\%), 2102.01 (46.37\%), 2102.19 (44.37\%), 2095.07 (43.41\%), 2103.16 (39.11\%), 2090.98 (32.27\%), 2094.00 (31.49\%), 2103.90 (27.66\%), 2102.98 (26.03\%), 2093.06 (22.49\%), 2090.36 (23.14\%), 2104.08 (21.11\%), 2104.93 (18.74\%), 2091.92 (13.13\%), 2088.83 (12.37\%), 2105.03 (11.00\%), 2106.00 (10.94\%), 2096.17 (10.73\%). IR (KBr, $\left.\mathrm{cm}^{-1}\right): 3175(\nu \mathrm{PhH})$, $2997(\nu \mathrm{CH}), 1541$ ( $\nu \mathrm{C}=\mathrm{C}),(2025 \mathrm{~s}, 1994 \mathrm{~m}, 1970 \mathrm{~m}, 1973 \mathrm{w})$ $(v \operatorname{sym}(\mathrm{C} \equiv \mathrm{O})), 826 \mathrm{sh}(\nu \mathrm{Cd}-\mathrm{N}), 297 \mathrm{sh}(\nu \mathrm{Cd}-\mathrm{Cl})$ and $(725 \mathrm{sh}$, $697 \mathrm{~s})(v \mathrm{P}-\mathrm{C}) .{ }^{1} \mathrm{H} \mathrm{NMR}\left(\mathrm{CD}_{3} \mathrm{Cl}, \delta, \mathrm{ppm}\right): 1.46-1.35(\mathrm{~m},-\mathrm{N}-$ $\left.\mathrm{C}-\mathrm{C}_{2}-\mathrm{CH}-, 4 \mathrm{H}\right), 1.71\left(\mathrm{~s}-,-\mathrm{N}-\mathrm{C}-\mathrm{CH}_{3}, 6 \mathrm{H}\right), 3.50-3.57$ (m, $\left.-\mathrm{CH}-\mathrm{CH}_{2}-\mathrm{N}-, 8 \mathrm{H}\right), 5.87-5.95(\mathrm{~m}, \mathrm{C}=\mathrm{CH}-\mathrm{C}, 2 \mathrm{H}), 6.72-$ $6.82(\mathrm{~m},-\mathrm{P}-\mathrm{CH}-\mathrm{P}, 2 \mathrm{H}), 7.27-8.31(\mathrm{~m}$, aromatic ring, $40 \mathrm{H})$, 8.30-8.48 (m, -N $=$ C $\underline{H}-\mathrm{C} \underline{H}-\mathrm{C} \underline{H}-\mathrm{C} \underline{\mathrm{H}}-\mathrm{C}-, 8 \mathrm{H})$. 


\subsection{Thin films preparation}

The molecular structure of PEPyr-diCd organic semiconductor is shown in figure 1. PEPyr-diCd (pale brown crystalline powder) has a chemical formula $\mathrm{CF}=\mathrm{C}_{40} \mathrm{H}_{66} \mathrm{~N}_{6} \mathrm{Cd}_{2} \mathrm{O}_{8} \mathrm{WP}_{4}$ and its molecular weight 2097.62. Thin films of PEPyr-diCd organic semiconductor were prepared by the thermal evaporation technique using a high vacuum coating unit (Edwards E 306 A, England). The vacuum during the deposition process was about $1 \times 10^{-4} \mathrm{~Pa}$. The films were deposited onto clean quartz substrates for structural and optical measurements, respectively. These substrates were carefully cleaned by nitric acid for $3 \mathrm{~h}$ and then rinsed by deionized water. The powder of PEPyr-diCd organic semiconductor was sublimated from quartz crucible heated gradually by molybdenum boat-shaped filament. The deposition rate and the film thickness were measured during the evaporation using a quartz crystal thickness monitor (Model TM-350 MAXTEK, Inc., USA) attached to the coating system. The grown film thickness of PEPyr-diCd organic semiconductor is $\cong 250 \mathrm{~nm}$ with deposition rate $0.30 \mathrm{~nm} \mathrm{~s}^{-1}$. PEPyr-diCd thin films were deposited onto both clean optically flat quartz substrates for spectrophotometric measurements and XRD analysis. A shutter, fixed near to the substrate was used to avoid any probable contamination on the substrates in the initial stage of evaporation process and to control the thickness of films accurately.

\subsection{Measurements}

Elemental analysis (EA) was performed using a Perkin Elmer 240E. Fourier transform infrared (FT-IR) spectra were recorded by a Spectrum One Spectrometer (Perkin Elmer) with spectral resolution of $0.01 \mathrm{~nm}$ using $\mathrm{KBr}$ pellets. ${ }^{1} \mathrm{H}$ NMR spectroscopy was carried out by a Varian Em-390$90 \mathrm{MH}_{\mathrm{Z}} \mathrm{NMR}$ spectrometer using $\mathrm{CDCl}_{3}$ as solvent and TMS as internal standard (chemical shifts in $\delta$ ppm). Mass spectra, fast atom bombardment-mass spectrometry (FAB-MS) were acquired with JEOL mass spectrometer JMS600, and are reported as mass/charge $(\mathrm{m} / \mathrm{z})$. Thermogravimetric analyses (TG, DTG and DTA) were performed with a DTG$60 \mathrm{H}$ Shimadzu simultaneous DTA/TG apparatus at heating rate of $10^{\circ} \mathrm{C} \mathrm{min}^{-1}$ under nitrogen (accuracy $0.01 \mathrm{mg}$ ). The absorbance spectra $(A)$, the transmittance spectra $(T)$ and reflectance $(R)$ of the complex were recorded at 200-1000 nm wavelength using Shimadzu UV-3101 UV-vis PC spectrophotometer at room temperature. All the measurements were estimated by taking into consideration the experimental errors in preparing and analysing the complex solution of PEPyr-diCd organic semiconductor as $\pm 1 \%$.

\subsection{Method of optical constants calculation}

To calculate the optical constants, the refractive index $(n)$, and the absorption index $(k)$ of PEPyr-diCd organic semiconductor complex thin film at different wavelengths, based on an absorbing (molar absorptivity with units of
$1 \mathrm{~mol}^{-1} \mathrm{~cm}^{-1}$ ) a PEPyr-diCd thin film, the spectrophotometric measurement of transmittance and reflectance measurements were used. The absorption coefficient $\alpha(\lambda)$, the refractive index $n(\lambda)$ and the absorption index $k(\lambda)$ were computed from the experimental measurements of the transmittance $T(\lambda)$, the reflectance $R(\lambda)$ and thickness film of the complex (c) according to equation (1) [21] (where $k=\alpha \lambda / 4 \pi$ ). Also, by solving equation (1) via elementary algebraic manipulation, refractive index is obtained as

$$
\begin{aligned}
& \alpha=\frac{1}{c} \ln \left[\frac{\left(1-R^{2}\right)}{2 T}+\sqrt{\frac{(1-R)}{4 T^{2}}+R^{2}}\right], \\
& R=\frac{(n-1)^{2}+k^{2}}{(n+1)^{2}+k^{2}} \text { and } \\
& n=\left(\frac{1+R}{1-R}\right)+\sqrt{\frac{4 R}{(1-R)^{2}}-k^{2}} .
\end{aligned}
$$

The computation can be carried out and the optical constants can be calculated. The optical constants $n$ and $k$ were estimated by taking into consideration the experimental errors in preparing the complex solution of PEPyr-diCd organic semiconductor as $\pm 1 \%$.

\subsection{Electrochemistry}

For voltammetric measurements, an EG\&G PAR Model 273A potentiostat with 250/270 research electrochemistry software version 4.0, manufactured by Princeton Applied Research Corporation (NJ) was used. It was interfaced with an electrode assembly model 303A (EG\&G) of static mercury drop electrode (SMDE) in platinum working electrode, $\mathrm{Ag} / \mathrm{AgCl}$ (in saturated $\mathrm{KCl}$ ) reference electrode and auxiliary electrode of platinum wire. Stirring was performed with a Teflon-coated bar at approximately $400 \mathrm{rpm}$ using a magnetic stirrer (KIKA Labortechinik, Germany). The reference electrode was separated from the bulk of the solution by a fritted-glass bridge filled with a solvent/supporting electrolyte mixture. Cyclic voltammograms (CVs) were recorded in a $\mathrm{CH}_{2} \mathrm{Cl}_{2}$ solution of $0.1 \mathrm{M}$ tetrabutyl ammonium perchlorate (TBAP) with a sample concentration of approximately $1 \times 10^{-3} \mathrm{M}$ and a scan rate from 10 to $250 \mathrm{mV} \mathrm{s}^{-1}$. A background spectrum was taken for each aliquot of electrolyte solution to ensure that the solvent and electrolyte had not become contaminated. The $\mathrm{CV}$ of cadmium dimer was recorded each day before setting the experiments in order to counteract any drift from the reference electrode.

\section{$2.7 X$-ray structural analysis of PEPyr-diCd (5a) organic semiconductor complex}

The XRD analyses were carried out by using Philips analytical X-ray BV, diffractometer type PW 1840. Radiation was provided by copper target $(\mathrm{Cu}$ anode $2000 \mathrm{~W}$ ) high-intensity $\mathrm{X}$-ray tube operated at $40 \mathrm{kV}$ and $25 \mathrm{~mA}$. Divergence and the receiving slits were 1 and 0.2 , respectively. 


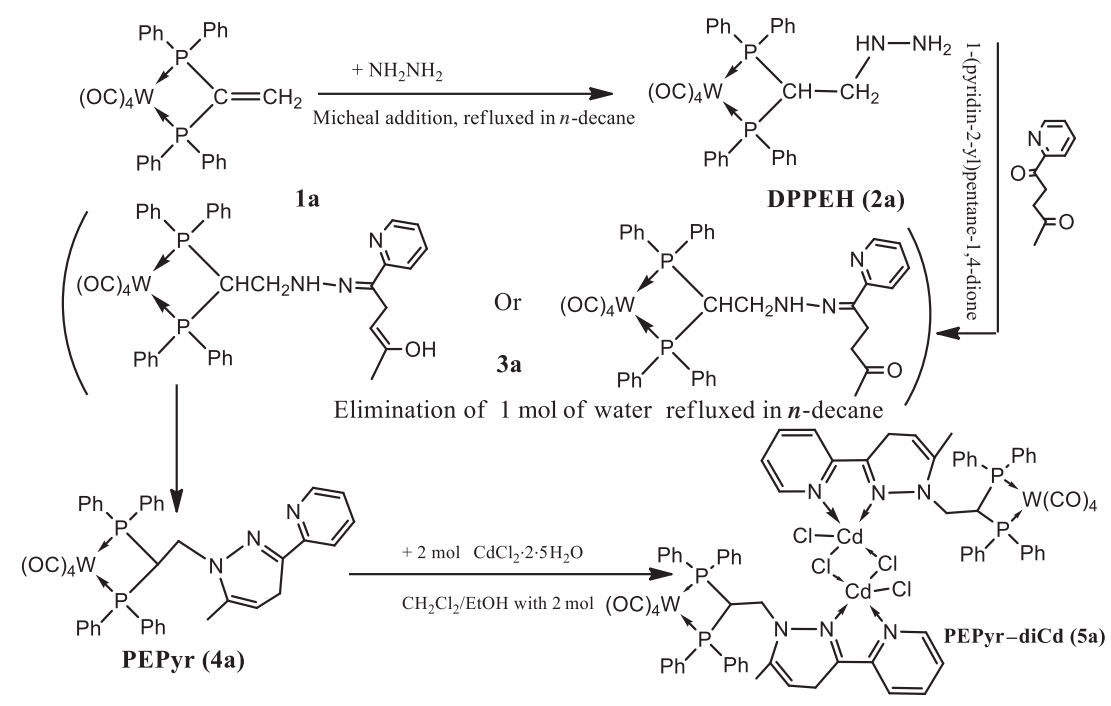

Figure 1. Synthesis of the dimer Cd-OSC complex.

\section{Results and discussion}

The synthesis and structural characterization of complexes, which have a dimer structure, was prepared by use of modification in previous literatures [14-17]. The binuclear PEPyrdiCd complex was isolated in good yield by gentle stirring of equivalent amounts of PEPyr in $\mathrm{CH}_{2} \mathrm{Cl}_{2}$ (as ligand) and $\mathrm{CdCl}_{2} \cdot 2.5 \mathrm{H}_{2} \mathrm{O}$ in dry ethanol in the open atmosphere at room temperature as shown in figure 1 . The pale brown powder complex product is soluble in chlorinated solvents and insoluble in alcohols, water, and ether and $n$-hexane. The structure of PEPyr-diCd complex was deduced from EA, FT-IR spectra, FAB-MS, TG/DTA, ${ }^{1} \mathrm{H}$ NMR spectroscopy and XRD measurements.

Instrumental techniques including FT-IR and ${ }^{1} \mathrm{H}$ NMR spectroscopies were applied for the characterization of the molecular structure of PEPyr-diCd (5a) organic semiconductor complex (see Section 2). The absence of the residual amine $\left(\mathrm{NH}_{2}\right)$ and $(\mathrm{NH})$ groups together in PEPyr (4a) and PEPyr-diCd (5a) with the appearance of a band typical of imine bonds $(\mathrm{HC}=\mathrm{N}-)$ was confirmed by NMR and FT-IR spectra. The mass spectrum and elemental analysis of PEPyr-diCd (5a) organic semiconductor complex had a good agreement with the proposed composition which is further confirmed by molecular ion peak $\mathrm{m} / \mathrm{z}=2095.24$ (96.74\%); the high resolution mass calculated from the formula $\mathrm{C}_{80} \mathrm{H}_{66} \mathrm{Cd}_{2} \mathrm{Cl}_{4} \mathrm{~N}_{6} \mathrm{O}_{8} \mathrm{P}_{4} \mathrm{~W}_{2}$ was $2097.62 \mathrm{amu}$.

\subsection{Spectroscopic studies of PEPyr-diCd (5a) organic semiconductor complex}

From the spectrum (figure 2), the purity calculation $\left(P_{\mathrm{i}}\right)$ of PEPyr-diCd (5a) organic semiconductor complex was calculated using the following equation [25]:

$$
P_{\mathrm{i}}=\frac{\mathrm{AI}_{\mathrm{i}}}{\mathrm{AI}_{\mathrm{r}}} \times \frac{\mathrm{NN}_{\mathrm{r}}}{\mathrm{NN}_{\mathrm{i}}} \times \frac{\mathrm{MW}_{\mathrm{i}}}{\mathrm{MW}_{\mathrm{r}}} \times \frac{M_{\mathrm{r}}}{M_{\mathrm{i}}} \times P_{\mathrm{r}} .
$$

Subscripts $\mathrm{i}$ and $\mathrm{r}$ relate to the test analyte and reference compound, respectively. AI is the absolute integral for a signal or set of signal, and $\mathrm{NN}$ in the corresponding number of nuclides. MW is the molecular weight (or, more correctly, the molar mass in $\mathrm{g} \mathrm{mol}^{-1}$ ), and $M$ is the weighed mass of material $(\mathrm{g})$. The purity of DPPEH $(98.67 \%)$ (2a), PEPyr (97.34\%) (4a), and PEPyr-diCd (98.48\%) (5a) complexes from ${ }^{1} \mathrm{H}$ and ${ }^{1} \mathrm{H}\left\{{ }^{31} \mathrm{P}\right\}$ NMR spectra are shown in figure 2 . It should be stressed that in DPPEH (2a) complex being the condensation of amide $(\mathrm{NH})$ and alkyl $\left(\mathrm{CH}, \mathrm{CH}_{2}\right)$ proton signal was detected. A broad signal was observed at $\delta=$ $2.20 \mathrm{ppm}$ of relative intensity $\mathrm{NH}$, each assigned to $(\mathrm{NH}$ and $\mathrm{NH}_{2}$ ) protons. In the case of other compounds the amide proton signals were absent. Two signals in DPPEH (2a) of relative intensity $\mathrm{H}$ and $2 \mathrm{H}$ at $\delta=2.64$ and $6.19 \mathrm{ppm}$ were observed and assigned to $\left(-\mathrm{CHC}_{2} \mathrm{NH}-\right)$ and (-PCHP-) proton coupling with $\mathrm{CH}$ and $\mathrm{CH}_{2}$ protons, respectively, ${ }^{2} \mathrm{~J}\left(-\mathrm{CHCH}_{2} \mathrm{NH}-\right) 2.24 \mathrm{~Hz}$ and ${ }^{1} \mathrm{~J}(-\mathrm{PCHP}-) 2.97 \mathrm{~Hz}$.

Five signals in PEPyr (4a) were observed at $\delta=6.49$ and $5.61 \mathrm{ppm}$ of relative intensity $\mathrm{H}$ and assigned to $-\mathrm{PC} \underline{\mathrm{HP}}-$ and $\mathrm{CH}_{3} \mathrm{CHN}$ - protons; at $\delta=2.82$ and $1.65 \mathrm{ppm}$ of relative intensity $2 \mathrm{H}$ and assigned to $-\mathrm{CHCH}_{2} \mathrm{~N}-$ and $\mathrm{NCC}_{2} \mathrm{CH}-$ protons. Finally, strong signal was observed at $\delta=2.32 \mathrm{ppm}$ of relative intensity $3 \mathrm{H}$ and assigned to $\mathrm{CH}_{3}$ protons. $\mathrm{PEPyr}-$ diCd (5a) complex were observed at $\delta=6.78$ and 5.90 ppm of relative intensity $\mathrm{H}$ and assigned to -PCHP- and $\mathrm{CH}_{3} \mathrm{CHN}$ - protons; at $\delta=3.53$ and $1.40 \mathrm{ppm}$ of relative intensity $2 \mathrm{H}$ and assigned to $-\mathrm{CHCH}_{2} \mathrm{~N}-$ and $\mathrm{NCC}_{2} \underline{\mathrm{CH}}_{-}$ protons. Strong signal was observed at $\delta=1.71 \mathrm{ppm}$ of relative intensity $3 \mathrm{H}$ and assigned to $\mathrm{CH}_{3}$ protons.

\subsection{Thermal analysis of PEPyr-diCd (5a) organic semiconductor complex}

Thermogravimetric analysis in nitrogen atmosphere was used to examine thermal properties of the obtained PEPyrdiCd (5a) complex. It is clear that thermal properties of the 


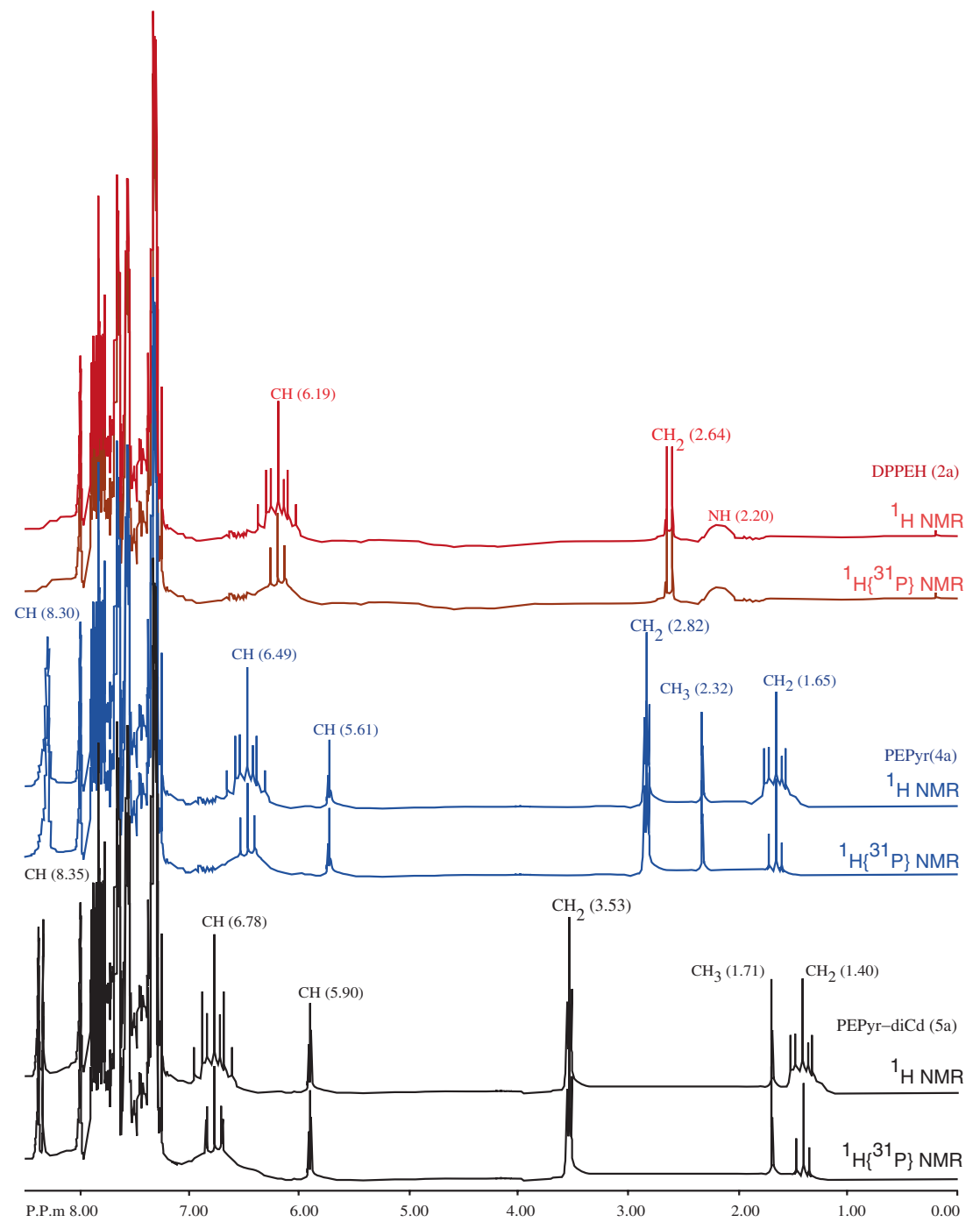

Figure 2. ${ }^{1} \mathrm{H}$ NMR and ${ }^{1} \mathrm{H}\left\{{ }^{31} \mathrm{P}\right\}$ spectra of dimer Cd-OSC complex.

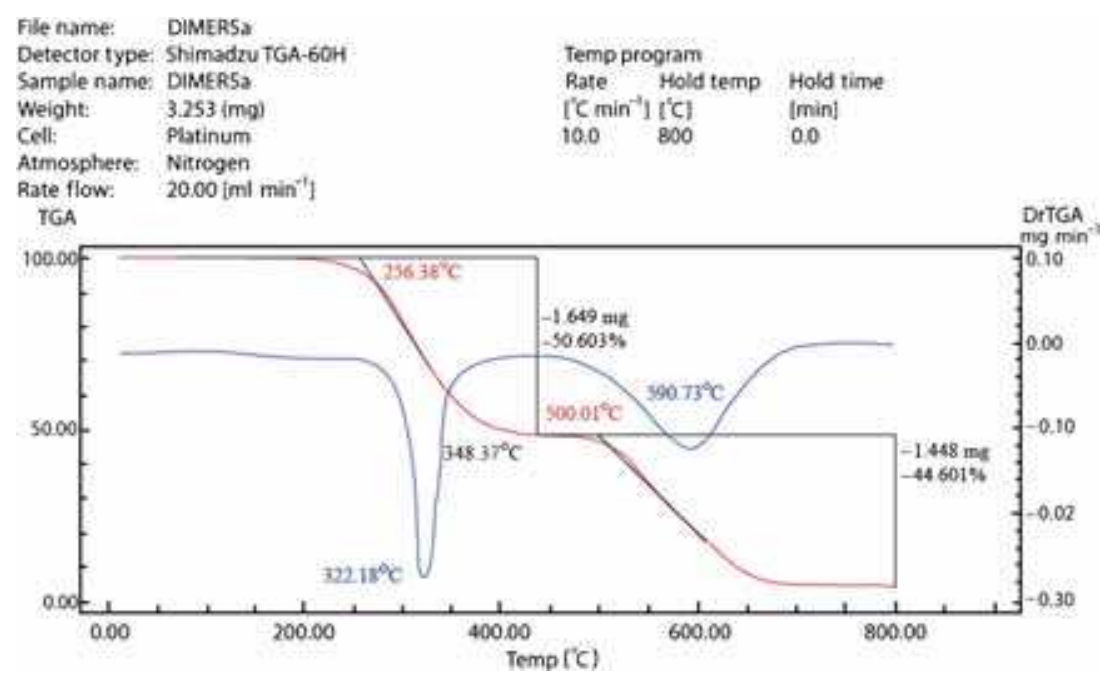

Figure 3. TG and DTA thermal curves of PEPyr-diCd organic semiconductor. 
compounds depend strongly on their chemical structure and different behaviour of pyridinyl pyridazine derivatives was observed. Thermal properties of the PEPyr-diCd (5a) complex were investigated in a temperature range from 0 to $800^{\circ} \mathrm{C}$ at a heating rate of $10^{\circ} \mathrm{C} \mathrm{min}^{-1}$. The typical thermal TG/DTA curves of the PEPyr-diCd (5a) are given in figure 3.

It is observed that TG/DTA curves fall into three ranges: (i) in the first step in TGA curve $\left(25-200^{\circ} \mathrm{C}\right)$, coordinated or uncoordinated water molecules were absent, because no weight loss was found. This is confirmed by IR and XRD results. The TG curve of PEPyr-diCd complex indicates that the PEPyr-diCd complex is thermally stable in the same temperature range, (ii) in the second step in TGA curve $\left(230-450^{\circ} \mathrm{C}\right)$, the initial weight loss is $50.603 \%(1.649 \mathrm{mg})$ correspond to the total mass of PEPyr-diCd (5a) complex value of $3.523 \mathrm{mg}$ that can be attributed to the evaporation of traces of some volatiles that present in the sample and splitting to half molecule of PEPyr-diCd (5a) complex. In the third step $\left(450-700^{\circ} \mathrm{C}\right)$, causing a further $44.601 \%(1.448 \mathrm{mg})$ weight loss to the removal of residual pyridinyl pyridazine derivatives that in the sample. The two ranges (ii) and (iii) correspond to the complete decomposition of PEPyr-diCd complex as deduced from mass loss calculation $95.21 \%$ (3.097 mg). The DTA is clear from these data that these mass losses are accompanied by exothermic (300, 375-475 and $\left.610^{\circ} \mathrm{C}\right)$ and endothermic $\left(322.18\right.$ and $\left.590.73^{\circ} \mathrm{C}\right)$ peaks within the temperature range of decomposition from 230 to $700^{\circ} \mathrm{C}$.

\subsection{X-ray structure determination of PEPyr-diCd (5a) organic semiconductor complex}

The XRD pattern for PEPyr-diCd complex in powder form is shown in figure $4 \mathrm{a}$ and $\mathrm{b}$. It is observed that the pattern has

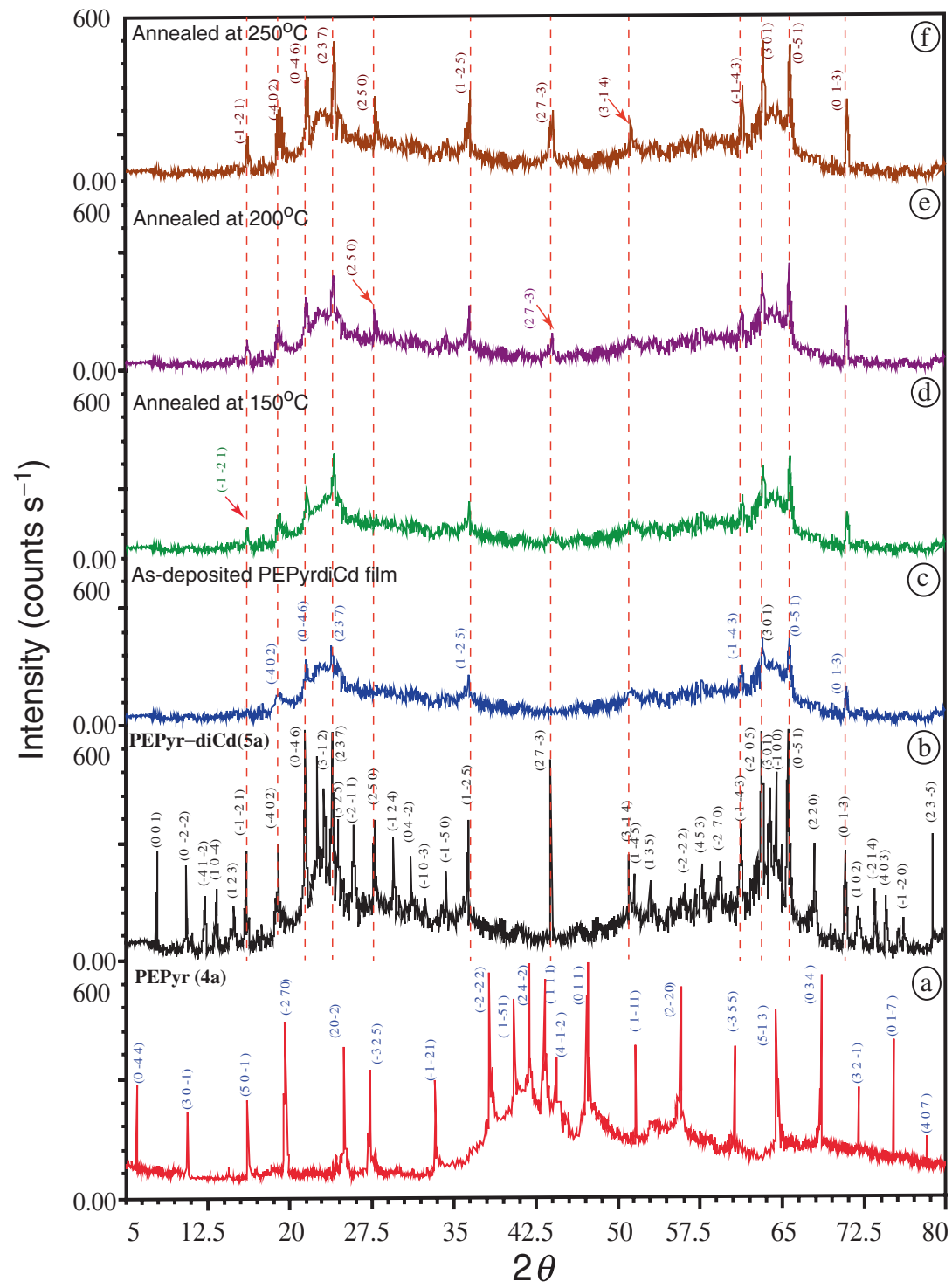

Figure 4. (a-f) XRD pattern of PEPyr-diCd organic semiconductor derivatives in powder form and thin films annealed at different temperatures. 
many diffraction peaks with different intensities indicating that the material in a powder form is of polycrystalline nature. Indexing of each diffraction peak was achieved by helping CHECKCELL program. The analysis shows that the PEPyr-diCd complex has orthorhombic crystal system and space group (Pbca) with lattice parameters: $a=10.3221 \AA$, $b=16.5742 \AA, c=25.345 \AA, \alpha, \beta$ and $\gamma=90.00^{\circ}$, respectively.

The XRD patterns for PEPyr-diCd complex and derivatives are shown in figure $4 \mathrm{a}$ and $\mathrm{b}$. The figure shows that the PEPyr-diCd complex has also a crystalline nature with preferred orientations of $(\overline{4} 02),(0 \overline{4} 6),(237),(1 \overline{2} 5),(\overline{1} \overline{4} 3)$, (301), $(0 \overline{5} 1)$ and $(01 \overline{3})$. The broadening of the XRD peak can be attributed to the contribution of different effects, such as, broadening due to smaller crystallite size $(D)$ and lattice microstrain $(\varepsilon)$ present in the material. The average crystallite size, $D$, and $\varepsilon$ were calculated using the Scherrer and Williamson-Hall equations

$$
D=\frac{\kappa \lambda}{\beta \cos \theta} \quad \text { and } \quad \varepsilon=\beta \frac{\cos \theta}{4 \sin \theta}-\frac{\kappa \lambda}{4 D \sin \theta},
$$

where $\lambda$ is the X-ray wavelength, $\kappa$ a constant of nearly 0.94 , $\beta$ the full-width at half-maximum intensity, FWHM, of the broadening peaks of PEPyr-diCd, and $\theta$ the angular position peak. From equation (3) it is clear that as $\beta$ increases the crystallite size $D$ decreases. The XRD pattern for PEPyrdiCd thin films with thickness of $250 \mathrm{~nm}$ is shown in figure $4 c-f$. Changes in the intensities of XRD peaks may result from grain growth and large amounts of intrinsic stresses. The stresses appear at the early stages of growth. The magnitude of these stresses depends upon both the film thickness at room temperature and annealing temperatures $\left(150,200\right.$, and $\left.250^{\circ} \mathrm{C}\right)$.

A multi-peaks are observed around $\left(2 \theta=4-80^{\circ}\right)$; this indicates that the nanocrystallites are preferably oriented with $(\overline{4} 02),(0 \overline{4} 6),(237),(1 \overline{2} 5),(\overline{1} \overline{4} 3),(301),(0 \overline{5} 1)$ and $(01 \overline{3})$ plane parallel to the surface of substrate. Increasing annealing temperatures did not effect on the peak position, which could be revealed by the independent of the interplaner distance $d_{h k l}$ on the annealing temperatures. However, there is an increase in the integrated intensity of diffraction peak as annealing temperature increases; this indicates that there are changes in the values of full-width at half-maximal intensity of the Brag diffraction peak, FWHM, the crystallite size, $D$ and the dislocation density, $\delta$, with the increase in annealing temperature. Annealing temperature up to $150^{\circ} \mathrm{C}$ increases the intensity of the peak at $\left(2 \theta=19.017^{\circ}, 20.010^{\circ}, 24.085^{\circ}\right.$, $36.540^{\circ}, 61.264^{\circ}, 63.217^{\circ}, 65.603^{\circ}$ and $\left.70.734^{\circ}\right)$, respectively, and also creates a new peak at $\left(2 \theta=16.146^{\circ}\right.$, $27.518^{\circ}, 43.962^{\circ}$ and $51.431^{\circ}$ ) corresponding to diffraction

Table 1. XRD data: $d$-spacing, crystallite size $D$, FWHM, $\varepsilon$-microstrain and $\delta$ dislocation density for PEPyr-diCd (5a) organic semiconductor complex and thin film [22-24].

\begin{tabular}{lcccccccccccc}
\hline Data/hkl & $(\overline{\mathbf{4}} 02)$ & $(0 \overline{\mathbf{4}} 6)$ & $(237)$ & $(1 \overline{\mathbf{2}} 5)$ & $(\overline{\mathbf{1}} \overline{\mathbf{4}} 3)$ & $(301)$ & $(0 \overline{\mathbf{5}} 1)$ & $(01 \overline{\mathbf{3}})$ & $(\overline{\mathbf{1}} \overline{1})$ & $(250)$ & $(27 \overline{\mathbf{3}})$ & $(3 \overline{\mathbf{1}} 4)$ \\
\hline -Spacing $(\AA)$ & 1.50 & 3.04 & 2.19 & 1.41 & 2.42 & 1.18 & 2.49 & 3.75 & 2.72 & 2.05 & 3.47 & 1.01 \\
Crystallite size $D$ & 39.55 & 52.17 & 46.75 & 67.09 & 92.45 & 46.82 & 53.90 & 83.94 & 37.62 & 52.73 & 47.10 & 48.46 \\
FWHM & 0.110 & 0.147 & 0.157 & 0.183 & 0.155 & 0.234 & 0.194 & 0.138 & 0.274 & 0.237 & 0.200 & 0.183 \\
$\varepsilon$-Microstrain & 0.220 & 0.137 & 0.145 & 0.097 & 0.122 & 0.083 & 0.073 & 0.180 & 0.164 & 0.198 & 0.089 & 0.211 \\
$\delta \times 10^{-4}(\mathrm{~nm})^{-2}$ & 2.475 & 3.749 & 3.657 & 1.869 & 2.857 & 0.924 & 8.673 & 4.790 & 3.089 & 8.167 & 10.11 & 10.94 \\
\hline
\end{tabular}

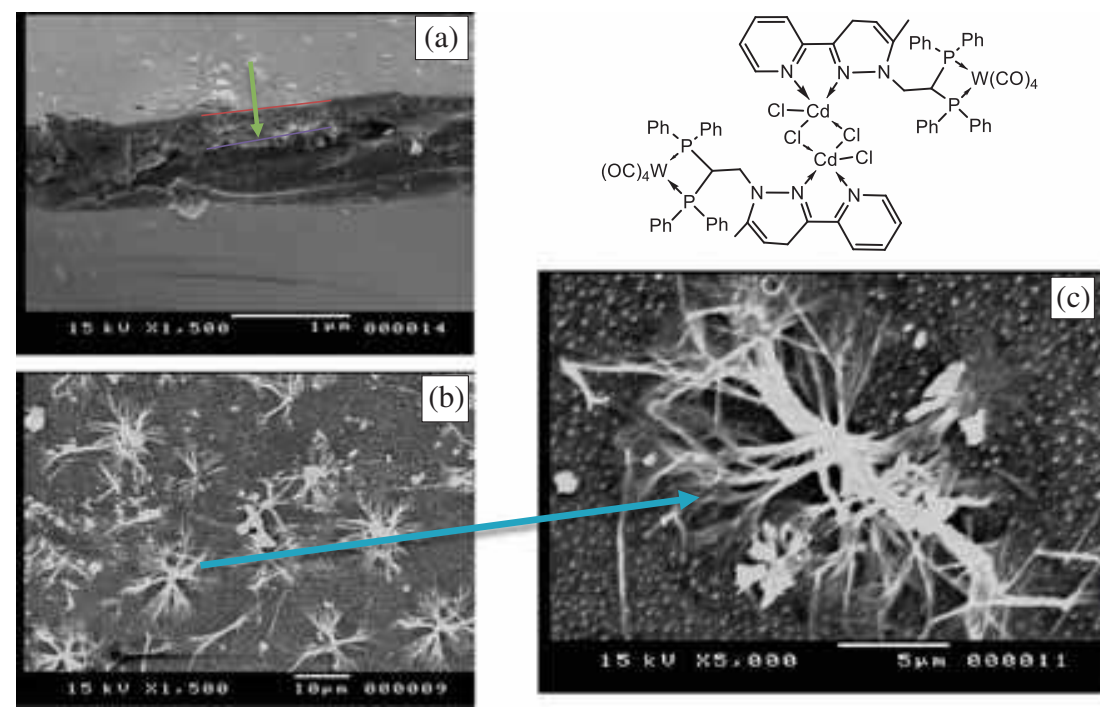

Figure 5. (a-c) SEM microphotograph of the PEPyr-diCd (5a) thin film. 
from $(\overline{1} \overline{2} 1),(250),(27 \overline{3})$ and $(3 \overline{1} 4)$, respectively; this indicates that increasing partial transformation of nanocrystallite PEPyr-diCd phase.

It is observed that the range crystallite size of PEPyr-diCd complex in powder and thin film can be calculated to be $\cong 39.55-92.45$ and $37.62-52.73 \mathrm{~nm}$ (table 1), respectively. The calculated values of interplaner distance $d$, microstrain $\varepsilon$, and the crystallite size $D$, were calculated using equation (3) for the main seven peaks observed in the XRD pattern for the PEPyr-diCd complex, listed in table 1. Also, the dislocation density $\delta$, of the synthesis PEPyr-diCd (5a) is given by Williamson and Smallman's equation: $\delta=f / D^{2}$, where $f$ is a factor, equals unity giving a minimum dislocation density. The calculated values of $\delta$ are given in table 1 .
Figure 5a displays the SEM by JEOL-JSM-5400 LV electron microscope) microphotographs (at $1 \mu \mathrm{m}$ and $15 \mathrm{kV} \times$ 1.500) of PEPyr-diCd (5a) thin film exhibits the average width of $\cong 250 \mathrm{~nm}$. As observed from figure $5 \mathrm{~b}$, that, the SEM microphotographs of PEPyr-diCd (5a) thin film (at $10 \mu \mathrm{m}$ and $15 \mathrm{kV} \times 1.500$ ) show details about the structure orientation of molecular structure. The SEM image shows the PEPyr-diCd (5a) thin film are free from any amorphous or other kind of crystalline phase particles. While, figure $5 \mathrm{c}$ (at $5 \mu \mathrm{m}$ and $15 \mathrm{kV} \times 5.000$ ) shows that surface topography and homogeneous distribution of elements (diCd, W, and P) in the structure of PEPyr-diCd (5a) thin film, in which the grain size evaluated from this study is comparable with the data obtained from XRD studies [26].
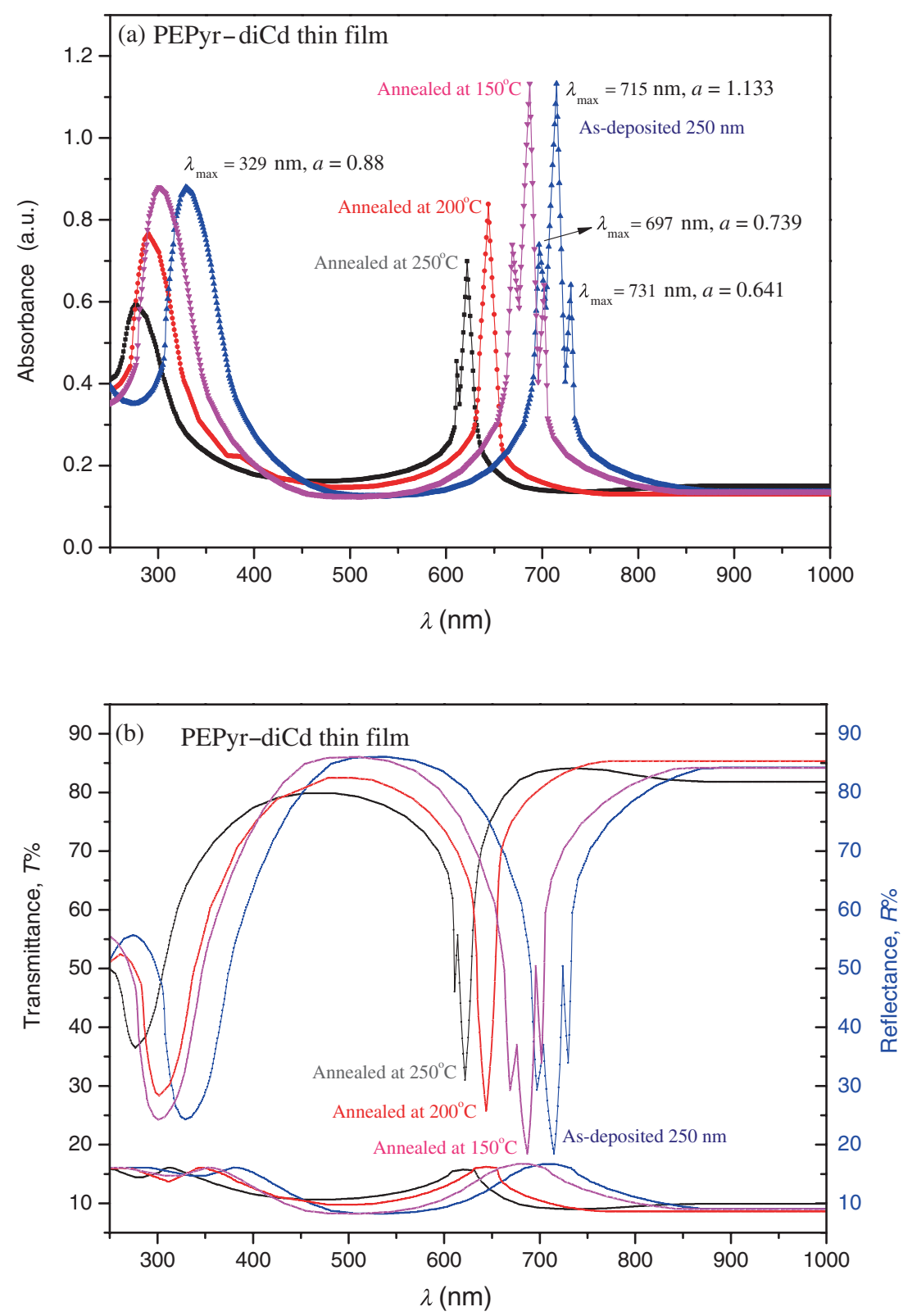

Figure 6. Absorption, transmission and reflection spectra of PEPyr-diCd thin films. 
3.4 Optical dispersion and dielectric properties of PEPyrdiCd (5a) thin film

The edge of the absorbance is observed in the lower wavelength region $(\lambda=329 \mathrm{~nm})$ and at the higher region $(697<\lambda$ $<731 \mathrm{~nm}$ ) as shown in figure 6a. The transmittance $T(\lambda)$ and reflectance $R(\lambda)$ spectra of PEPyr-diCd (5a) organic semiconductor thin film were measured to investigate their optical properties and they are shown in the UV-vis spectrum of PEPyr-diCd thin film at room temperature $(300 \mathrm{~K})$ as shown in figure 6b. The PEPyr-diCd thin film of thickness $250 \mathrm{~nm}$ was deposited on a quartz substrate that did not absorb light itself in the visible, near IR, and UV ranges. The diagram shows that there are two regions in the spectra: low wavelength $(\lambda<400 \mathrm{~nm})$, the total sum of $T(\lambda)$ and $R(\lambda)$ is less than unity because part of the light is absorbed (absorption region). A high intensity broadened peak is observed for PEPyr-diCd in the reflectance behaviour at spectral range $300<\lambda<870 \mathrm{~nm}$.

The absorption is high according to the transmission diagram, as all light that is neither reflected nor transmitted must be absorbed and the difference $1-T(\lambda)-R(\lambda)$ is equal to the absorption $A$. The oscillation in the values of $T(\lambda)$ and $R(\lambda)$ is a result of light interference in the considered wavelength range. In figure $6 \mathrm{~b}$ it is shown that in the wavelength region of $225<\lambda<1000 \mathrm{~nm}$ it is not a regular spectrum. The diagram shows the annealing temperature slightly blue shifts the transmission edge to higher wavelength and reduces the peak intensity of the interference. This blue shift effect in the transmittance $(T)$ or absorbance spectra with annealing temperature has been attributed mainly to two possible reasons; (i) nitrogen out-diffusion from bulk organic material, and (ii) inter-diffusion of $\mathrm{N}$-transition metal atoms near the interface of organic material [27].

\subsection{Energy gap determination}

To obtain information about direct or indirect inter-band transitions, the spectral dependence of the absorption coefficient $\alpha$ near the fundamental absorption edges within the framework of band-to-band transition theory was used for analysis. Thus, the optical gap of the PEPyr-diCd thin film is calculated by differentiating the natural logarithm of absorption coefficient $\alpha$ equation after multiplying it by photon energy, transforming the equation to be linear in $(m)$ which can be also written as [28]

$$
\begin{aligned}
\alpha & =\left(\frac{A}{h v}\right)\left(h v-E_{\mathrm{g}}\right)^{m} \text { differentiation } \frac{\mathrm{d}[\ln (\alpha h v)]}{\mathrm{d}(h v)} \\
& =\frac{m}{h v-E_{\mathrm{g}}},
\end{aligned}
$$

where $A$ is an energy-independent constant, $m$ governs the transition type and $E_{\mathrm{g}}$ the optical band gap. The derivative of equation (1) was treated by origin lab 7 program on the calculated absorption coefficient as shown in figure 7. Plotting the corresponding data of the inverse on the left-hand side of differentiation equation $v s$. photon energy results in a linear curve in the absorption edge region only of slope $1 / m$ and intercept of $E_{\mathrm{g}} / m$ as shown in figure 7. The calculated $m$ value is close to 0.5 , which indicates that the transition type is directly allowed. The optical band gap of PEPyr-diCd thin film (this value of energy gap corresponding to the difference between HOMO and LUMO levels) of PEPyr-diCd complex was determined from the intercept. The difference between $\left(E_{\mathrm{g}}^{\mathrm{opt}}\right)$ and $\left(E_{\mathrm{g}}^{\text {trans }}\right)$ is referred as the
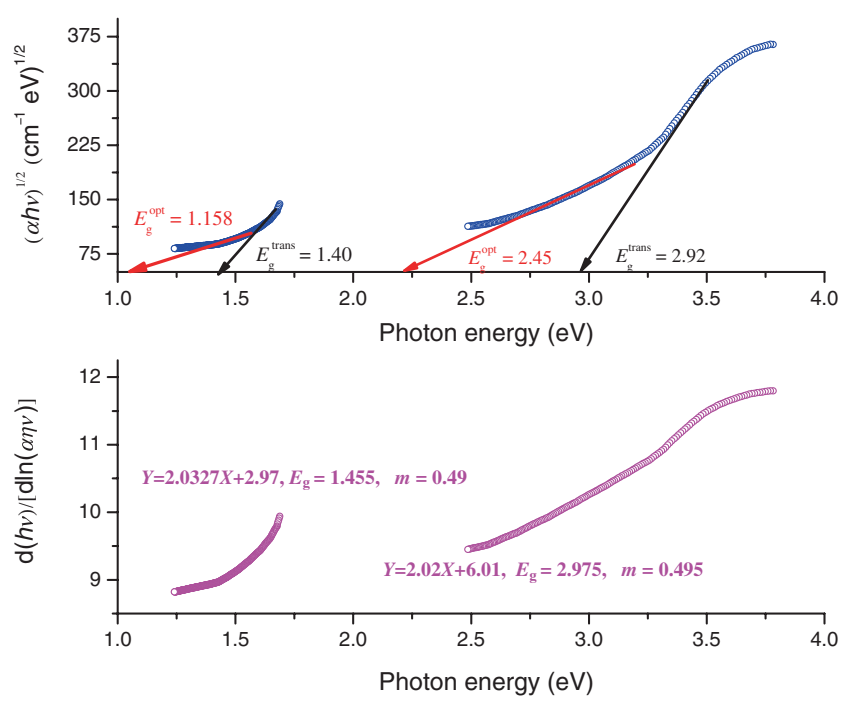

Figure 7. Plot of $(\alpha h v)^{1 / 2}\left(\mathrm{~cm}^{-1} \mathrm{eV}\right)^{1 / 2}$ and $\mathrm{d}(h v) /[\mathrm{d} \ln (\alpha h v)] v s$. photon energy $h v$.

Table 2. Values of energy gap for PEPyr-diCd thin film by different calculation methods.

\begin{tabular}{lcccccc}
\hline & \multicolumn{3}{c}{$(\alpha h v)^{1 / 2}\left(\mathrm{~cm}^{-1} \mathrm{eV}\right)^{1 / 2}$} & & $\mathrm{~d}(h v) /[\mathrm{d} \ln (\alpha h v)]$ & \\
\cline { 2 - 3 } Method/sample & $E_{\mathrm{g}}^{\text {opt }}(\mathrm{eV})$ & $E_{\mathrm{g}}^{\text {trans }}(\mathrm{eV})$ & $E_{\mathrm{B}}(\mathrm{eV})$ & $E_{\mathrm{g}}(\mathrm{eV})$ & References \\
\hline PEPyr-diCd & 1.158 & 1.40 & 0.242 & & 1.455 & Present work \\
PEPyr-diCd & 2.45 & 2.92 & 0.47 & & 2.975 & Present work \\
PMI & - & 2.30 & - & - & {$[29]$} \\
PDI & - & 2.39 & 0.280 & - & {$[29]$} \\
MEH-PPV : C 70 & 1.67 & - & 0.492 & 2.06 & {$[30]$} \\
B6-TCNQ & - & - & - & & 2.03 & {$[31]$} \\
Rh.B & - & 1.97 & 0.364 & & 2.03 & {$[32]$} \\
\hline
\end{tabular}


binding energy $\left(E_{\mathrm{B}}\right)$. The values of $\left(E_{\mathrm{g}}^{\mathrm{opt}}\right),\left(E_{\mathrm{g}}^{\text {trans }}\right)$ and $\left(E_{\mathrm{B}}\right)$ of PEPyr-diCd organic semiconductor thin film in comparison to that of other organic complexes are listed in table 2 .

\subsection{Determination of optical constants of PEPyr-diCd organic semiconductor thin film}

The determination of the refractive index $(n)$, the extinction coefficient $(k)$, and the optical conductivity $\sigma(w)=\sigma_{1}+\mathrm{i} \sigma_{2}$ (a complex function where $\left(\sigma_{1}\right)$ is the real part and $\left(\sigma_{2}\right)$ is the imaginary part of the optical conductivity) of PEPyrdiCd organic semiconductor complex is important for optical communications according to equation (1).

The real $\left(\sigma_{1}\right)$ and imaginary $\left(\sigma_{2}\right)$ parts of the optical conductivity are expressed by [33]

$$
\begin{aligned}
& \sigma_{1}=\omega \varepsilon_{2} \varepsilon_{0} \quad \text { and } \quad \sigma_{2}=\omega \varepsilon_{1} \varepsilon_{0} \text { since } \\
& \varepsilon_{1}=\varepsilon_{\text {real }}=n^{2}-k^{2}, \quad \varepsilon_{2}=\varepsilon_{\text {img }}=2 n k
\end{aligned}
$$

where $\varepsilon_{1}, \varepsilon_{2}, \omega$ and $\varepsilon_{0}$ are the real (or the normal dielectric constants), imaginary (the absorption associated with radiation by free carrier) parts of the dielectric constants, the angular frequency, and the free space dielectric constant, respectively.

Figure 8a and $\mathrm{b}$ illustrates the dependence of both $n$ and $k$ on photon energy in the UV-vis region of the PEPyr-diCd complex. The $n$ and $k$ values increase sharply with the increase in photon energy nearing 1.75 , then decrease rapidly till the peak of $n=2.1$ at photon energy equal $2.25 \mathrm{eV}$. On the other hand, the $n$ value at a photon energy of 3.25 decreases slowly until $3.65 \mathrm{eV}$, but the value of $k$ increases slowly until $3.75 \mathrm{eV}$. As it is observed from the figure spectra that, both $n$ and $k$ show a normal dispersion at higher photon energy $\geq 4 \mathrm{eV}$, and a single oscillator model can be used to explain the behaviour in this region of spectra. The dispersion is a measure of the change of the refractive index $(n)$ and absorption coefficient $(k)$ with wavelength. It can be explained by applying the electromagnetic theory to the molecular structure of organic semiconductor thin film. If incident photon energy impinges on an atom or a molecule, the bound charges vibrate at the frequency of the incident wave. The bound charges (free carriers) have resonance frequency at a certain wavelength. When the vibrated bound charges frequency is in resonance with the incident one, $n$ and $k$ have a similar behaviour [34].

It can be seen that $\left(\sigma_{2}\right)$ (the imaginary part of the optical conductivity) increases with the increase in photon energy with a little drop in the two ranges of photon energy from 1.75 to 2.25 and 3.00 to $3.50 \mathrm{eV}$. While, $\left(\sigma_{1}\right)$ (the real part of the optical conductivity) has two distinct peaks of 325 and $225 \Omega^{-1} \mathrm{~cm}^{-1}$ at 1.75 and $3.75 \mathrm{eV}$, respectively.

From Sellmeier single term dispersion relation, the average inter-band oscillator wavelength $\left(\lambda_{0}\right)$ can be evaluated from relation

$$
\left(n^{2}-1\right)^{-1}=\left(n_{\infty}^{2}-1\right)^{-1}-\left(\frac{\lambda_{0}^{2}}{\left(n_{\infty}^{2}-1\right)^{2}}\right)\left(\frac{1}{\lambda^{2}}\right) .
$$
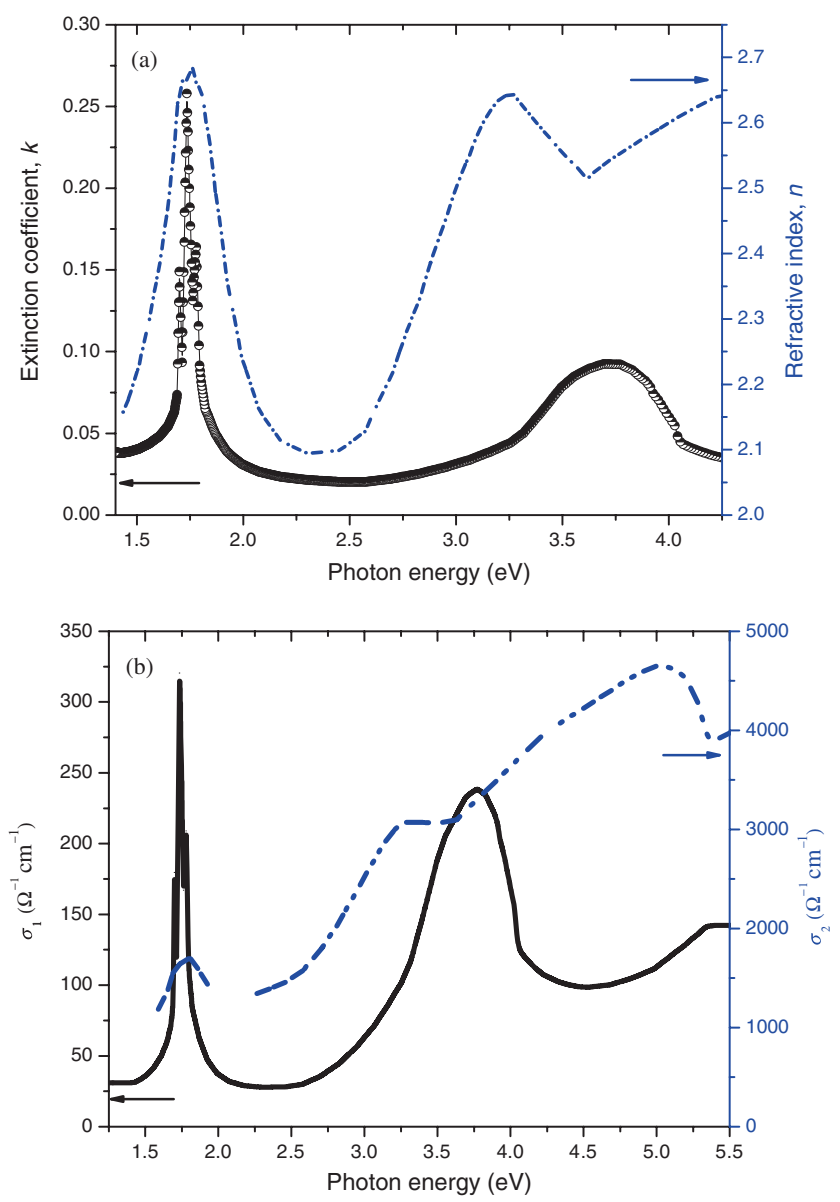

Figure 8. Plot of photon energy dependence of: (a) refractive index $(n)$ and extinction coefficient $(k)$ and $(\mathbf{b})$ real $\left(\sigma_{1}\right)$ and imaginary $\left(\sigma_{2}\right)$ optical conductivity of PEPyr-diCd thin film.

The values of $\lambda_{0}$ can be calculated from the slope of the curve and it is equal to 315.3 and $455.58 \mathrm{~nm}$, while the calculated values of the refractive index at infinite wavelength $\varepsilon_{\infty}=n_{\infty}^{2}=5.294$ and 2.995 and it is shown in figure 9 . The values of the dispersion parameters of PEPyr-diCd complex compared with other organic semiconductors are given in table 3.

\subsection{Cyclic voltammetry}

The redox behaviours of imino-phosphine dimer cadmium (II) complexes were studied through first three cyclic voltammetry as shown in figure 10 . The $\mathrm{CV}$ of each of the complexes (2a-5a) was first compared with that of their respective tungsten tetracarbonyl complex (1a) (one reversible oxidation at $201 \mathrm{mV}$ ) to identify whether any redox reactions are coming specifically from the complex (1a), and not the cadmium centre.

The peak current in a $\mathrm{CV}$ containing only one species is described by

$$
i_{\mathrm{p}}=\left(2.69 \times 10^{5} n^{3 / 2} A D^{1 / 2} v^{1 / 2} C^{*}\right),
$$



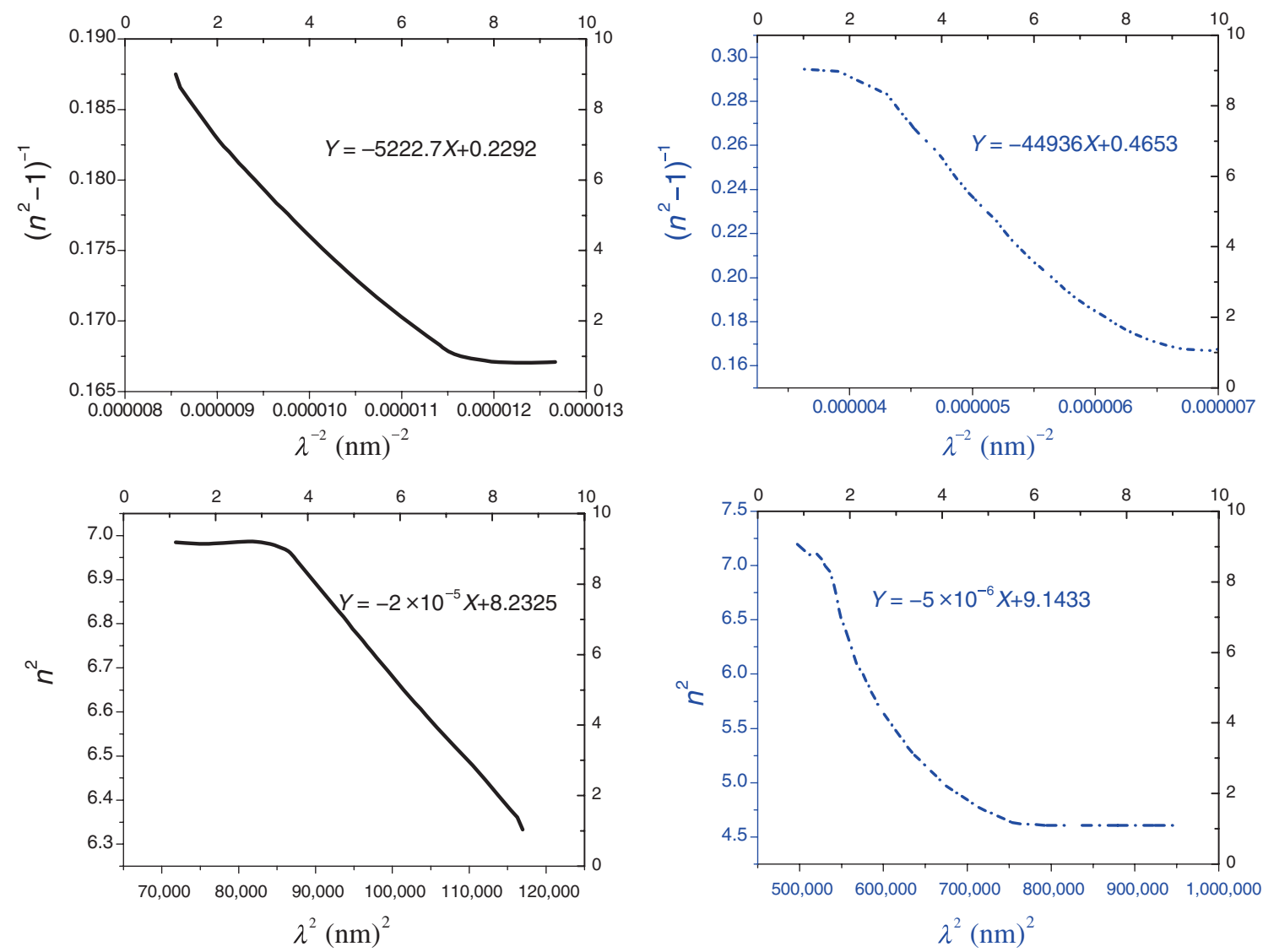

Figure 9. Plot of $n^{2}$ and $\left(n^{2}-1\right)^{-1}$ vs. $\lambda^{2}$ and $\lambda^{-2}$, respectively, for PEPyr-diCd thin film.

Table 3. Dispersion parameters of PEPyr-diCd complex compared with other organic semiconductors.

\begin{tabular}{|c|c|c|c|c|c|c|c|c|c|}
\hline Sample & $E_{\mathrm{d}}(\mathrm{eV})$ & $E_{\mathrm{o}}(\mathrm{eV})$ & $\lambda_{\mathrm{o}}(\mathrm{nm})$ & $S_{\mathrm{o}}\left(10^{13} \mathrm{~m}^{-2}\right)$ & $\begin{array}{c}E_{\mathrm{o}} / S_{\mathrm{o}} \times 10^{-14} \\
\left(\mathrm{eV} \mathrm{m}^{2}\right)\end{array}$ & $\varepsilon_{\infty}$ & $\varepsilon_{\mathrm{L}}$ & $\begin{array}{c}\left(N / m^{*}\right) \\
\left(\mathrm{kg}^{-1} \mathrm{~m}^{-3}\right)\end{array}$ & References \\
\hline PEPyr-diCd & 0.242 & 8.043 & 315.3 & 4.39 & 18.32 & 5.294 & 8.701 & $2.45 \times 1040$ & Present work \\
\hline PEPyr-diCd & 0.47 & 3.833 & 455.58 & 1.04 & 36.85 & 2.995 & 13.087 & $1.23 \times 1040$ & Present work \\
\hline PMI & 8.53 & 5.58 & - & - & - & - & - & - & [29] \\
\hline PDI & 6.34 & 4.71 & - & - & - & - & - & - & [29] \\
\hline MEH-PPV : C70 & 10.61 & 3.89 & 319.28 & 2.68 & 14.51 & 1.93 & - & - & [30] \\
\hline Rh.B & 8.6 & 4.5 & 275.5 & 2.50 & 18.00 & 2.88 & 2.98 & $4.7 \times 1046$ & [31] \\
\hline
\end{tabular}

The values listed in table 3 are also in comparison with other compounds reported in literature [29-32].

at $25^{\circ} \mathrm{C}$ where $i_{\mathrm{p}}$ is the peak current, $n$ the number of electrons transferred, $A$ the electrode area, $D$ the diffusion coefficient of the species, $v$ the scan rate, and $C^{*}$ the bulk concentration of the species. The difference between $E_{\mathrm{p}}$ and the point where current is half that at $E_{\mathrm{p}}, E_{\mathrm{p} / 2}$, is $56.5 / n \mathrm{mV}$ at $25^{\circ} \mathrm{C}$, where $n$ is the number of electrons transferred. Note that for a Nernstian system, $E_{\mathrm{p}}$ should be independent of scan rate, but $i_{\mathrm{p}}$ will depend on the square root of scan rate. Another useful piece of information is that the separation of anodic and cathodic peaks is about $(59 / n) \mathrm{mV}$ at $25^{\circ} \mathrm{C}$. It is very difficult to achieve a $59 / n \mathrm{mV}$ splitting at most solid electrodes.
Compound $2 \mathrm{a}$ exhibits a different behaviour with two distinct and separate oxidation couples at 41 and $150 \mathrm{mV}$. The separation between the two oxidation couples is quite large (109 mV). Compound 4a exhibits two quasi-reversible oxidations at 251 and $175 \mathrm{mV}$. The separation between the two couples is small $(76 \mathrm{mV})$, but can still be distinguished visually. The CV of PEPyr-diCd (5a) organic semiconductor appears to have two quasi-reversible oxidations at 543 and $441 \mathrm{mV}$.

The difference between the two median potentials of oxidation couples $E_{1 / 2}^{\mathrm{o}}(1 \mathrm{a})-E_{1 / 2}^{\mathrm{o}}(1 \mathrm{c})$ and $\left[E_{1 / 2}^{\mathrm{o}}(2 \mathrm{a})-E_{1 / 2}^{\mathrm{o}}(2 \mathrm{c})\right]$ for $\mathrm{CVs}$ of imino-complexes $2 \mathrm{a}, 4 \mathrm{a}$ and $5 \mathrm{a}$ are 100 [88], 88 
[50] and 76 [139] $\mathrm{mV}$, respectively [35,36]. It is found that the separation between redox couples for complexes $4 \mathrm{a}$ and $5 \mathrm{a}$ are much smaller than that of compound $2 \mathrm{a}$, which is likely due to the structure of the complex, as compounds $4 \mathrm{a}$ and $5 \mathrm{a}$ both have $\mathrm{C}=\mathrm{C}, \mathrm{N}=\mathrm{C} \pi$ bonds present while complex $2 \mathrm{a}$ does not (without aromatic ring). Table 4 summarizes the $E_{1 / 2}$ values for the four imino-phosphine complexes.

It is proposed that when the first oxidation occurs on the tungsten tetracarbonyl metal for $4 \mathrm{a}$ and $5 \mathrm{a}$ complexes, the positive charge can be delocalized through the $\mathrm{C}=\mathrm{C}$ and $\mathrm{C}=\mathrm{N}$ double bond into the complex itself. As a result, the second oxidation would be easier, which renders the second oxidation $E_{1 / 2}^{\mathrm{o}}(2 \mathrm{c})$ to occur on pyrazole ring at a potential closer to the first oxidation $E_{1 / 2}^{\mathrm{o}}(1 \mathrm{c})$, and also, the positive charge in PEPyr-diCd (5a) organic semiconductor can be delocalized through the $\mathrm{C}=\mathrm{C}$ and $\mathrm{C}=\mathrm{N}$ double bond into the cadmium dimer complex.

As a consequence, the difference between the first oxidation and second oxidation is smaller. On the contrary, compound 2a lacks the $\pi$ system and, therefore, cannot delocalize the charge away from the tungsten centre for $4 \mathrm{a}$. The CVs of variable scan rates from 10 to $250 \mathrm{mV}$ were recorded for each compound and a plot of intensity of the current vs. the scan rate (figure 11) shows a linear relationship indicating that all processes are diffusion-controlled single electron redox couples.
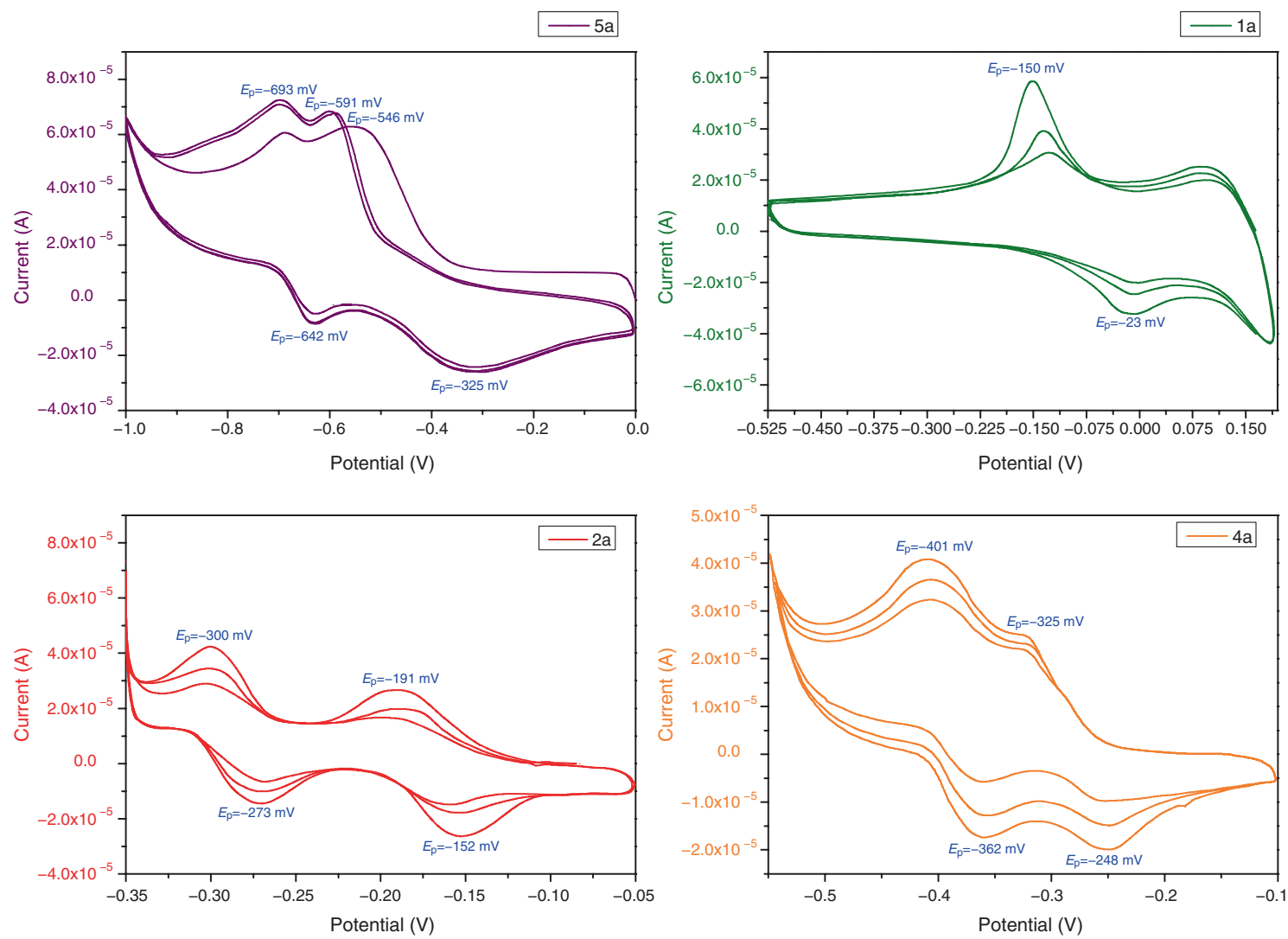

Figure 10. Cyclic voltammograms of PEPyr-diCd (5a) organic semiconductor complex at scan rate of $100 \mathrm{mV} \mathrm{s}^{-1}$ in $\mathrm{CH}_{2} \mathrm{Cl}_{2}$ solution containing $0.1 \mathrm{M}$ TBAP.

Table 4. Values of redox potentials for dimer cadmium complexes, their cathodes and anodes peak separations.

\begin{tabular}{|c|c|c|c|c|c|c|c|c|c|}
\hline \multirow[b]{2}{*}{ Comp. } & \multicolumn{2}{|c|}{$E_{\mathrm{pa}}(\mathrm{mV})$} & \multicolumn{2}{|c|}{$E_{\mathrm{pc}}(\mathrm{mV})$} & \multirow[b]{2}{*}{$\Delta E(1)$} & \multirow[b]{2}{*}{$\Delta E(2)$} & \multirow[b]{2}{*}[E_{1/2}^{\circ}(1\mathrm{a})-E_{1/2}^{\circ}(1\mathrm{c})]{} & \multirow[b]{2}{*}[E_{1/2}^{\circ}(2\mathrm{a})-E_{1/2}^{\circ}(2\mathrm{c})]{} & \multirow[b]{2}{*}[E_{1/2}^{\circ}(1\mathrm{a})-E_{1/2}^{\circ}(2\mathrm{a})]{} \\
\hline & $E_{1 / 2}^{\circ}(1 \mathrm{a})$ & $E_{1 / 2}^{\circ}(2 \mathrm{a})$ & $E_{1 / 2}^{\circ}(1 \mathrm{c})$ & $E_{1 / 2}^{\circ}(2 \mathrm{c})$ & & & & & \\
\hline $1 \mathrm{a}$ & 150 & - & 23 & - & 127 & - & 127 & - & - \\
\hline $2 a$ & 150 & 041 & 250 & 129 & 27 & 39 & 100 & 88 & 109 \\
\hline $4 a$ & 251 & 175 & 339 & 225 & 39 & 77 & 88 & 50 & 76 \\
\hline $5 a$ & 543 & 441 & 619 & 302 & 51 & 266 & 76 & 139 & 102 \\
\hline
\end{tabular}

$\Delta E=E_{\mathrm{pa}}-E_{\mathrm{pc}}$ for $E_{1 / 2}^{\mathrm{o}}$ and values corrected using the $E_{1 / 2}^{\mathrm{o}}$ value of tungsten tetracarbonyl complex (1a). 


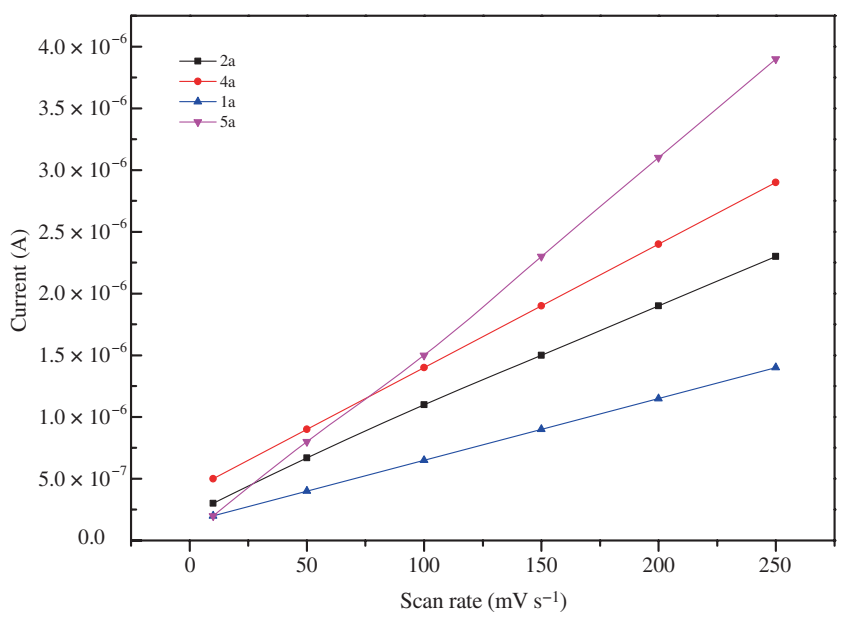

Figure 11. Relation between current (A) vs. scan rate $\left(\mathrm{mV} \mathrm{s}^{-1}\right)$ for four imino-phosphine complexes.

\section{Conclusions}

A series of imino-phosphine complexes have been synthesized by the addition of a $\mathrm{CdCl}_{2} \cdot 2.5 \mathrm{H}_{2} \mathrm{O}$ to an iminophosphine and characterized using FT-IR, ${ }^{1} \mathrm{H}$ NMR spectroscopies, and thermal analysis. In this work, the structure of PEPyr-diCd (5a) organic semiconductor crystalline nanostructure thin film was determined using XRD and SEM microphotograph. It is observed that the range crystallite size of PEPyr-diCd complex in powder and thin film can be calculated to be $\cong 39.55-92.45$ and $37.62-52.73 \mathrm{~nm}$ by using modified Scherrer's formula. All the films exhibit orthorhombic crystal structure with a space group Pbca. The microstructural parameters as a function of annealing temperature were evaluated.

The optical property of PEPyr-diCd organic semiconductor complex has been investigated. For this purpose, absorption and reflection measurements of the solution were performed in the 225-1000 $\mathrm{nm}$ spectral range. Optical band gaps of organic semiconductor were calculated from absorption measurements. Also, optical parameters of complex such as absorption coefficient, extinction coefficient, refractive index, and dielectric constant were determined. In addition, dispersion analysis of refractive index was performed and related dispersion parameters such as dispersion energy, single oscillator energy, and moment values were determined. The imaginary part of the optical conductivity $\left(\sigma_{2}\right)$ increases with the increase in photon energy with a little drop in the two ranges of photon energy from 1.75 to $2.25 \mathrm{eV}$ and 3.00 to $3.50 \mathrm{eV}$; while $\left(\sigma_{1}\right)$ is the real part of the optical conductivity which has two distinct peaks of 325 and $225 \Omega^{-1} \mathrm{~cm}^{-1}$ at 1.75 and $3.75 \mathrm{eV}$, respectively.

The redox behaviours of all four imino-phosphine complexes were studied through cyclic voltammetry. All four complexes compounds in the series exhibit two quasireversible oxidation peaks. The $\left[E_{1 / 2}^{\mathrm{o}}(1 \mathrm{a})-E_{1 / 2}^{\mathrm{o}}(2 \mathrm{a})\right]$ values for imino-phosphine complexes $2 \mathrm{a}, 4 \mathrm{a}$ and $5 \mathrm{a}$ are 109, 76, and $102 \mathrm{mV}$, respectively. The separation between the two oxidation couples is much smaller for compounds $4 \mathrm{a}$ and $5 \mathrm{a}$ when compared with that of compound $2 \mathrm{a}$, which has been attributed to the presence of $\pi$-bonds in the imino-phosphine chelating ligands, allowing for charge delocalization upon the first oxidation occurring.

Optical absorption (table 2) and cyclic voltammetry measurements $(\Delta E(2)$ from table 4) revealed that PEPyr-diCd organic semiconductor complex is wide-band gap semiconductors with high electron affinity (LUMO level $\sim-2.975$ to $-2.66 \mathrm{eV}$ ) and high positive oxidation potential. These properties indicate that PEPyr-diCd organic semiconductor complex as good candidates as acceptor materials for organic heterojunction solar cells.

\section{References}

[1] Sworakowski J, Bielecka U, Lutsyk P and Janus K 2014 Thin Solid Films $\mathbf{5 7 1} 56$

[2] Joua J, Chen S, An C, Peng S, Ting T, Shyue J, Chin C, Chen C and Wang C 2015 Dyes Pigm. 113341

[3] Galagan Y, Shanmugam S, Teunissen J, Eggenhuisen T, Biezemans A, Van Gijseghem T, Groen W and Andriessena R 2014 Sol. Energy Mater. Sol. Cells 130163

[4] Zhang J and Hoshino K 2014 Des. Appl. Biomed. Eng. 169. doi: 10.1016/B978-1-4557-7631-3.00004-1

[5] Al-Hossainy A F and Ibrahim A 2014 J. Optoelectron. Adv. Mater. 161472

[6] Soon O J and Jun Y L 2011 Sol. Energy Mater. Sol. Cells 95 1102

[7] Sang K J, Bodakuntla T, Choongik K, Kwon T L, Jun Y L and Sung Y S 2015 Dyes Pigm. 114146

[8] Evans R C, Douglas P and Winscom C 2006 J. Coord. Chem. Rev. 2502093

[9] Arbuzova S N, Volkov P A, Ivanova N I, Gusarova N K, Larina L I, Kazheva O N, Alexandrov G G, Dyachenko O A and Trofimov B A 2011 J. Organomet. Chem. 6962053

[10] Casares J A, Espinet P, Martín-Alvarez J M, Espino G, PérezManrique M and Vattier F 2001 Eur. J. Inorg. Chem. 2001 289

[11] Zhao C Q, Jennings M C and Puddephatt J R 2008 J. Inorg. Organomet. Polym. Mater. 18143

[12] Burt J, Levason W and Reid G 2014 Coord. Chem. Rev. 260 65

[13] Shepherd R E, Chen Y, Kortes R A and Ward M S 2000 Inorg. Chim. Acta 30330

[14] Badr A M, El-Amin A A and Al-Hossainy A F 2008 J. Phys. Chem. C 11214188

[15] Al-Hossainy A F and Ibrahim A 2015 Mater. Sci. Semicond. Proc. 3813

[16] Al-Hossainy A F and Ibrahim A 2015 Opt. Mater. 46131

[17] Hassan F S M, Al-Hossainy A F and Mohamed A E 2009 Phosphorus Sulfur Silicon 1842996

[18] Awad I M A, Hassan F S M, Mohamed A E and Al-Hossainy A F 2004 Phosphorus Sulfur Silicon Relat. Elem. 1791251

[19] Waradi Al-Ali M, Hammouti B, Hadda T, Shareiah R and Rzaigui M 2013 Res. Chem. Intermed. 392451 
[20] Warad I, Hammouti B, Ben Hadda T, Boshaala A and Haddad S F 2013 Res. Chem. Intermed. 394011

[21] Yahiaa I S, Farag A A M, Cavas M and Yakuphanoglue F 2013 Superlattices Microstruct. 5363

[22] Ivanova T, Harizanova A, Koutzarova T and Vertruyen B 2010 Mater. Lett. 641147

[23] Lalitha S, Sathyamoorthy R, Senthilarasu S, Subbarayan A and Natarajan K 2004 Sol. Energy Mater. Sol. Cells 82187

[24] Kandjani A E, Tabriz M F, Moradi O M, Mehr H R R, Kandjani S A and Vaezi M R 2011 J. Alloys Compd. 5097854

[25] Mahajan S and Singh I P 2012 Magn. Reson. Chem. doi: $10.1002 / \mathrm{mrc} .3906$

[26] Xingtao Z, Lili W, Jiajie H, Zhenhua L and Shuili Y 2014 Desalination 34743

[27] Spruytte S G, Coldren C W, Harris J S, Wampler W, Krispin P, Ploog K and Larson M C 2001 J. Appl. Phys. 894401
[28] El Sayed A M, Said G, Taha S, Ibrahim A and Yakuphanoglu F 2013 Superlattices Microstruct. 6247

[29] Kisnisci Z, Yüksel Ö F and Kus M 2014 Synth. Met. 194 193

[30] Yakuphanoglu F 2008 J. Phys. Chem. Solids 69949

[31] Yakuphanoglu F and Arslan M 2007 Physica B 393304

[32] Farag A A M and Yahia I S 2010 Opt. Commun. 2834310

[33] Sakr G B, Yahia I S, Fadel M, Fouad S S and Romcevic N 2010 J. Alloys Compd. 507557

[34] Jedamzik R, Reichel S and Hartmann P 2014 SPIE Proc. 8982-51

[35] Tiedemann M A, Mandell C L, Chan B C and Nataro C 2014 Inorg. Chim. Acta 422193

[36] Landman M, Pretorius R, Fraser R, Buitendach B E, Conradie M M, Van Rooyen P H and Conradie J 2014 Electrochim. Acta 130104 